\title{
A Journey of Writing the Self
}

\author{
ROSA HONG CHEN \\ Simon Fraser University
}

\begin{abstract}
In this paper I present a narrative trajectory into self-formation and academic inquiry. Through a series of poems, as both mode of process and inquiry itself, the paper renders a complex of yearning, hopes, predicaments, confusions, fears of failure, and struggles of my innermost being upon the journey of research inquiry. Employing poetic narrative as a method of inquiry, I demonstrate that the process to bring relevant query to bear on poetic narrative suggests a practice of understanding and transforming experience and knowledge, through calling out and responding to the self and the other.
\end{abstract}

\section{Prologue}

When we write about ourselves, we embark on a journey whose destination may be the revelation of what we value and how we interpret reality. Language, in the general sense, whether prosaic or poetic, conveys, and, in turn, shapes our thoughts. Our thoughts are shaped, as some linguists assert, by the vocabulary and grammar of the language we speak. Language is thus important in that it "constitutes, rather, a powerful cognitive filter through which we come to view and understand" (Danesi, 2004, p. 58) ourselves in relation to the world. And, to accept the American anthropologist Edward Sapir's (1921) contention, we are, essentially, what we speak.

Narrative, hence, foregrounds self-formation and the "negotiation of identity" (Florio-Ruane, 2001, p. 80), and offers one way of reaching the self. For writing the self engages in evolving and emergent critical inquiry and self-reflection. In the process of writing the selves, narrators pose critical questions about themselves and others by revealing their inner conflicts. According to H. Richard Milner (2007), engaging in these questions can bring to the awareness and consciousness that are "known (seen), unknown (unseen), and unanticipated (unforeseen)" (p. 395) to the selves of the narrators. In writing the selves, narrators are always reflecting about themselves in relation to others, questing, and responding to themselves and the outer world.

Exploring narrative inquiry in poetic form provides us with a more imaginative mode of cognition, poetic language being distinguished for its merits by its means. Neapolitan philosopher Giambattista Vico, in his landmark treatise of 1725, The New Science, patently describes the faculty of mind that guides our attempts to make sense of things as poetic logic. For Vico, poetic logic is expounded as a universal form of imaginative thinking that allows us to understand the world on our own terms. Through poetic narrative as a method of inquiry, I seek to demonstrate that the process to bring relevant inquiry to bear on poetic narration is potentially transformative. This is manifestly displayed in a case in point to follow.

(C) Copyright 2006. The author, Rosa Chen, assigns to the SFU Educational Review the right of first publication and educational and non-profit institutions a non-exclusive license to use this document for personal use and in courses of instruction provided that the article is used in full and this copyright statement is reproduced. Any other usage is probibited without the express permission of the author. 


\section{A Voice Reaching Out}

\section{I}

I narrate, you narrate,

We, he, and they;

Whom of all I venerate.

Dr. Poetry delights us all

In his eloquence of narrating.

Narrative, a method to seek,

A way to live;

In life, everyday is real,

In scholarly realm as well.

Once a cloud shaded my quest,

Life stories weren't the best.

Who are at all interested here?

The academic world in the least.

The flowing words in streams of narration,

The trivial bits and pieces, worst or best

Who are on earth interested here?

\section{II}

Is it not a thin dream

Floating among quantitative reels?

Is it not a papery tree

Quivering amalgamation of data between?

Slippery in "validity" as it means;

How the austere "reliability" does it meet?

In this academic world

A sullen thud fell upon my head,

A patter cloaked my quest.

And the publications to request,

Then the promotion one of the best.

The most, but not the least,

What about the SSHRCish ${ }^{1}$ success?

I certainly want,

As you, he, and they,

To be acclaimed as the best!

\section{III}

But doors are slamming,

And water is splashing.

Stern shutters are up putting,

Facing narrative inquiries.

I want to write something,

${ }^{1}$ SSHRC is the abbreviation of The Social Sciences and Humanities Research Council of Canada. It is a federal agency that promotes and supports university-based research and training in the social sciences and humanities. 
Something to feel, to sense,

Something to touch and breathe;

I want to prose stories,

Stories that rise; that fall,

Stories that dance; that sing,

Appropriate to the occasion still,

However fitful the gleam is uphill.

I'm an academic, or one to be,

As you, he, and they,

Deeply mused; yet restless,

To grab it; yet willing to pass it.

\section{IV}

Then I pack my fears and horrors, My curiosity, my anxiety, my memories.

I juggle among tangled vines, Upon the road not much trodden.

Resolved to shine away,

From where the sunlight is fallen.

I gaze upon the horizon,

The road of which rapidly widens.

As my hand is moving,

Audibly, life starts murmuring.

Words endeavour to educe

What life has evinced.

Here babbling, here doodling

Dr. Poetry is pronouncing

There emerge my impromptus

From fervid facility of phrases.

\section{V}

I compose a discordant melody at times, While a peculiar gloom is afflicted.

As my hand is moving,

A tremor pervades my frame:

"Am I duly egotistical,

To break the brazen shield of Self?

Or to embarrass my fine demeanour?

In a darkened tunnel,

I wonder; I demur.

Sentiment of fear creeps upon my layers.

Words at once make smoky rings,

Phrases wretch my moving hand.

$\mathrm{Oh}$, the equivocal nature of stories!

But I want to scribble;

A feeling of wild amazement not crippled

Indulges my vague hopes meaningful. 


\section{VI}

I press down the beating of my heart, I feel the raindrops on my shoulders,

I hear the rattling of sashes

Which tie a maiden's bosom;

I exert my ears to commingled noises;

I vision the rising of the tempest;

I dread the flood of tears pouring.

The unceasing radiation of gloom and glow,

Dazzles my eyes in glaring gold.

There my scribbling words

Dip into the wavy objects of the globe.

My hand is still scribbling

And my senses are sharpening

As if light steps on adjoining vision.

Words arrest my attention

Through a strange alternation.

\section{VII}

I narrate my being,

A being that is from awed attention;

I elicit a poetic inquiry,

An inquiry that burnishes my knowing;

I reminisce my stories,

Stories that I'm reliving;

I loosen my institutional pulse

A pulse that ripens my becoming.

This is my journey of narrative

That starts from the horizon.

I then prance about

So as to accord with the rhythm of life;

I would fain trot out

As if broaden my erudition;

I earnestly gallop at length

So as to envisage a faraway prairie.

\section{VIII}

A vivacious warmth that storying beholds

To heat a settled apathy;

My profuse words dart the waves of life,

For you, for me

For him, and for them.

Fretting our life, freeing our minds

A rumination, a self-discovery

Through expressions ensuing.

Words, and phrases, 
Poetic inquiry. And narrative knowing:

Dotting, darting,

Gleaming, and flickering.

Here a feeble encrimsoned light,

Here a luminous reflection;

Now a story in the frame of mirror

Radiates an interpretation in scroll.

\section{VIV}

I fumble in the glacial creek

Where I defrost my burning feet;

I tumble through the dank water,

Where I bathe my thirsty limbs;

I stumble over a fissure of view,

Which I sew with silk thread;

I trip into a furrow,

Where I plant flower seeds.

My hand is still moving,

Transgressing the past

And abutting on the present

I cry out inquiring:

"Who am I?"

A voice protracted echoing:

From a silent tarn in the mountain:

"Who am I?"

\section{Epilogue}

I have offered a glimpse of the journey of writing myself, manifesting one of multiple ways of arriving at the question, "Who am I?" in the personal, academic, and social realms. I thus invite you, the reader, to experience the intricacies of feelings, knowing, and experience on the trajectory of narrating in poetry, serving as both research inquiry and method to conduct the inquiry. I also invite you to share, in experiencing the narrative writing of another, an imaginative act on the narrator and the narrated. Narrative inquiry, is ultimately a relational practice of understanding and transforming experience and knowledge through self-expressions and reflections calling for a corresponding interaction between self and reality. Such self-reflective inquiry can call forth self-understanding, unfolding an ontological and epistemological quest(ing).

Thus, I further suggest that the narrative approach, whether or not in poetic form, while developing an understanding of individual experience, creates an alternate perspective on the development of personhood and one's knowledge of reality, which pedagogues are bent on undertaking. Through my own journey of poetic narrating, I hope to explore the pedagogical implications that exist between the narrative paradigm and education. 


\title{
References
}

Danesi, M. Poetic Logic: The Role of Metaphor in Thought, Language, and Culture. Madison, WI: Atwood Publishing, 2004.

Florio_Ruane, S. Teacher Education and the Cultural Imagination: Autobiography, Conversation, and Narrative. Mahwah, NJ: Lawrence Erlbaum Associates, Inc., 2001.

Milner IV, H. R. "Race, Culture, and Researcher Positionality: Working through Dangers Seen, Unseen, and Unforeseen." Educational Research 36, no 7 (2007): 288-400.

Sapir, E. Language. New York: Harcourt, Brace, and World, 1921.

Vico, G. The New Science. Bergin and Fisch, 1725/1984.

\begin{abstract}
About the Author
I am a second year PhD student in the Faculty of Education at Simon Fraser University. My area of interest lies in language, literacy, and literature; autobiography, cultural identity, poetry, and narrative as research; epistemology and philosophy of education. In 2006 I published two articles in refereed journals. Poem, I Want to Go Beyond, has appeared in recent issue of Poetry Canada. I was a university professor in China, went to the US in 1993, and immigrated to Canada in 2001. I am a member of AERA (American Educational Research Association), CSSE (Canadian Society for the Study of Education), AAAL (American Association for Applied Linguistics), and a member of CFP (Canadian Federation of Poets). Email address: hrchen@sfu.ca, jinnanrosachen@hotmail.com.
\end{abstract}

